\title{
INTENSI PERILAKU DAN RELIGIUSITAS GENERASI MILLENIALS TERHADAP KEPUTUSAN PEMBAYARAN ZIS MELALUI PLATFORM DIGITAL
}

\author{
Oleh : \\ Mega Rachma Kurniaputri \\ Universitas Indonesia - Kajian Timur Tengah dan Islam \\ megarachma15@gmail.com \\ Rindani Dwihapsari \\ Universitas Indonesia - Kajian Timur Tengah dan Islam \\ rindani.dwihapsari@gmail.com \\ Nurul Huda \\ Universitas Yarsi - Fakultas Ekonomi \\ Universitas Indonesia, Kajian Timur Tengah dan Islam \\ nurul.huda@yarsi.ac.id \\ Nova Rini
}

STIE Muhammadiyah Jakarta/Universitas Indonesia - Kajian Timur Tengah dan Islam Nvrin207@yahoo.com

\begin{tabular}{l}
\hline Article Info \\
\hline Article History: \\
Received 23 July - 2020 \\
Accepted 20 August - 2020 \\
Available Online \\
O7 Sept - 2020
\end{tabular}

Keyword :

intention behavior,

religiousity, zaqat, infaq,

alms.

\begin{abstract}
Indonesia has the largest number of Muslim in the world, therefore the potential of zakat can reach 3.46 percent of GDP. But in fact, total collection of zakat is not accordance with its potential. One of the solution which can be done is approach the millennial generation and take advantage of current financial technology. Along with the issue, the purpose of this research is to examine the faktors that influence millennials generation in Jabodetabek in their decision to pay zakat, infaq and alms through digital platforms. Based on the literature review, behavioral intentions will affect individual behavior of consuming an item or service, which in this study is behavior in deciding to pay ZIS through a digital platform such as OVO, GoPay, mobile banking. In addition, religiosity is a form of individual behavior towards their religion and it can influence the decisions to pay ZIS. By using PLS-SEM analysis, as well as survey data from the distribution of questionnaires to 153 respondents, it was found that intention behavior was significantly influential in the decision to pay ZIS through digital platform. While religiosity has no significant effect on the decision to pay ZIS through a digital platform.
\end{abstract}

\section{PENDAHULUAN}

Dewasa ini dalam menghadapi era industri 4.0, kemajuan teknologi semakin banyak digunakan oleh masyarakat. Salah satu penyebabnya adalah memberikan kemudahan bagi semua pekerjaan dan kehidupan sehari-hari, seperti misalnya dalam membeli makanan ringan secara online. Tentunya melalui kemajuan teknologi informasi seperti sekarang ini dapat memberikan dampak positif ataupun negatif di dalam kehidupan masyarakat. Dampak negative yang dapat muncul adalah melakukan pemborosan sedangkan salah satu dampak positif yang sudah pasti dirasakan adalah dapat meningkatkan kecepatan fleksibilitas produksi meningkatkan layanan kepada pelanggan dan meningkatkan penghasilan (Santoso 2019). 
Hal init terbukti dengan sebagian besar bentuk bisnis dan pelayanan menjadi berkembang secara dinamis dengan kemampuan mereka menyediakan sistem online. Pada sisi lainnya, di Era Industri 4.0 ini dapat dipandang sebagai bentuk revolusioner untuk pertumbuhan dan penyebaran agama secara digital. Indonesia sendiri merupakan Negara dengan penduduk mayoritas muslim terbesar di dunia turut merasakan dampak dari perkembangan teknologi internet. Salah satunya dalam memperkenalkan sistem ekonomi syariah sebagai jawaban untuk sebuah kesejahteraan. Penduduk Indonesia mayoritas adalah Islam sehingga membuat Indonesia memiliki potensi dan peluang yang besar untuk menjadi pusat perekonomian syariah dunia. Hampir seluruh komponen masyarakat siap untuk memajukan ekonomi syariah, selanjutnya hanya bagaimana memulai secara tepat agar semua dapat bersinergi bersama.

Instrument yang paling penting dalam ekonomi syariah terkhusus dalam meningkatkan kesejahteraan Negara adalah dengan zakat, infak, dan shadaqah (ZIS). Sebagai solusi untuk mencapai sebuah kesejahteraan, ZIS tidak hanya berlandaskan terhadap ketauhidan atau keimanan seseorang saja, namun ZIS juga memiliki dimensi yang berpengaruh pada bidang sosial dan ekonomi masyarakat. Memiliki 87,18\% penduduk Muslim dari total penduduk Indonesia, menggambarkan bahwa potensi ZIS di negara ini sangat besar. Potensi tersebut juga diakibatkan dari transisi demografi yang semakin mendominasi generasi produktif usia muda dan pertumbuhan ekonomi Indonesia dengan bertambahnya jumlah masyarakat kelas menengah di era ekonomi digital yang telah mencapai 52 juta jiwa (Avisena 2020).

Adapun kesadaran masyarakat dalam membayar ZIS setiap tahunnya semakin meningkat, terlebih dengan ditunjang oleh kemajuan teknologi yang memudahkan setiap orang dalam menunaikan ZIS. Masyarakat masa kini cenderung melakukan pembayaran ZIS dengan media online. Sebagai contoh, Badan Amal Zakat Nasional (BAZNAS) yang melebarkan sayapnya dengan menggandeng 26 kanal digital seperti social media, toko online e-commerce, artificial intelligence, dan layanan keuangan digital seperti Kitabisa, Jenius, Gopay, Gojek, OVO, Tcash, Kaskus, Lenna, Shopee, Tokopedia, Lazada, Matahari Mall, Oy! Indonesia dan Line (KNKS 2019).

Dalam skala nasional, jumlah penghimpunan dana ZIS di Indonesia melalui OPZ resmi mengalami kenaikan dari tahun 2009-2017, hal ini dapat dilihat pada tabel berikut:
Tabel 1. Pertumbuhan Penghimpunan ZIS

Tahun 2009-2017

\begin{tabular}{cccc}
\hline Tahun & $\begin{array}{c}\text { ZIS } \\
\text { (Milyar Rp) }\end{array}$ & $\begin{array}{c}\text { Pertumbuhan } \\
(\boldsymbol{\%})\end{array}$ & $\begin{array}{c}\text { Pertumbuhan } \\
\text { PDB }(\boldsymbol{\%})\end{array}$ \\
\hline 2009 & 1,200 & 30.43 & 4.9 \\
2010 & 1,500 & 25.00 & 6.1 \\
2011 & 1,729 & 15.27 & 6.5 \\
2012 & 2,212 & 27.94 & 6.23 \\
2013 & 2,639 & 19.30 & 5.78 \\
2014 & 3,300 & 25.05 & 5.02 \\
2015 & 3.650 & 36.00 & 10.61 \\
2016 & 5.012 & 51.29 & 37.46 \\
2017 & 6.224 & 62.37 & 24.06 \\
\hline \multicolumn{4}{c}{ Rata-rata } \\
\hline
\end{tabular}

Sumber: BAZNAS, 2018

Berdasarkan tabel tersebut, dapat diketaui bahwa jumlah penghimpunan ZIS selalu meningkat dari 2009 sampai 2017. Pertumbuhan yang positif dan signifikan terjadi di tahun 2015 yang mencapai $\mathrm{Rp} \mathrm{3,650} \mathrm{Trilyun,} \mathrm{lalu} \mathrm{meningkat}$ tajam kurang lebih sebesar $40 \%$ pada tahun 2016 , mencapai Rp 5,017 Trilyun. Sementara itu pada tahun 2017 terjadi kenaikan kurang lebih sebesar $25 \%$ yaitu Rp 6,224 Trilyun. Namun sejatinya pencapaian ini terbilang masih jauh dari potensi zakat yang diharapkan, dimana menurut Ketua Badan Amil Zakat Nasional (BAZNAS) Prof. BambangSudibyo, mengatakan bahwa potensi zakat di Indonesia dengan regulasi yang sudah berjalan saat ini dapat meraih sejumlah Rp213,3 triliun atau (1,57\% dari PDB) (BAZNAS 2019). Bahkan jumlah ini bisa semakin meningkat sejalan dengan adanya peraturan baru yaitu zakat diterapkan sebagai pengurang pajak. Maka potensi zakat di Indonesia pun dapat mencapai Rp 462 Trilyun atau sebesar 3,46\% dari nilai PDB.

Adapun setelah melihat data diatas, menjadi sebuah tantangan baru bagi stakeholders untuk meminimalisir gap yang ada diantara jumlah penghimpunan ZIS dengan jumlah potensi zakat. Salah satu pendekatan yang dapat dilakukan di era industry 4.0 ini adalah dengan mengacu kepada kelompok generasi millennial yang berusia 18-36 tahun (usia produktif), dimana dari segi pendapatan biasanya kelompok usia produktif sudah memumpuni untuk menunaikan pembayaran ZIS. Berikut merupakan data jumlah penduduk millennial yang berdomisili di Jakarta pada tahun 2019: 


\section{Gambar 1. Jumlah Penduduk DKI Jakarta Berdasarkan Usia}

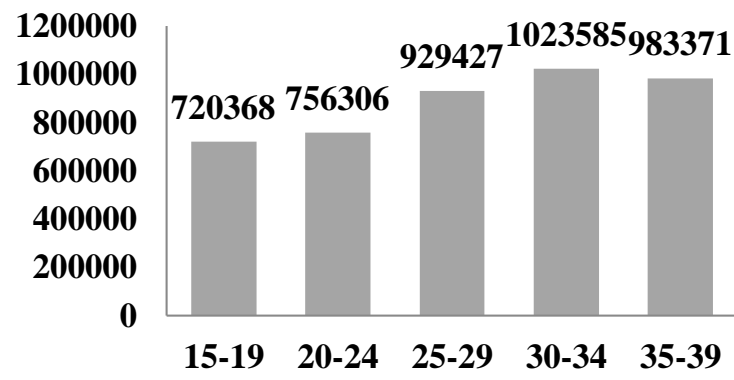

Sumber: Badan Pusat Statistik, 2019

Badan Pusat Statistik (BPS) DKI Jakarta memaparkan bahwa jumlah usia produktif yang tergolong kelompok millennial berjumlah sekitar 4.413.057 juta. Selain itu, berdasarkan data dari Asosiasi Penyelenggara Jasa Internet Indonesia (APJII) sebanyak 171,17 juta jiwa atau sebanyak 64.8 persen pengguna internet berusia sekitar 1529 tahun atau berada pada kelompok millennial (Haryano 2019). Sehingga dengan jumlah tersebut pengoptimalan zakat pada kelompok millennial melalui media online atau digital menjadi pilihan yang harus diprioritaskan.

Melakukan optimalisasi terhadap zakat digital tentu juga harus fokus terhadap kelayakan dari fasilitas yang dimiliki agar dapat menarik intensi kaum millennial untuk mengeluarkan dana ZIS. Fasilitas yang dicari biasanya berupa fasilitas yang memudahkan, dan mampu meluaskan target muzakki dan munfiq. Intensi perilaku dari para millennial dengan adanya zakat digital ini dinilai mampu meningkatkan keputusan mereka dalam menyalurkan dana ZIS. Adapun selain dari intensi perilaku, faktor keagamaan seseorang juga perlu untuk dilihat. Keagamaan seseorang (religiusitas) dinilai mampu menjadi dorongan kuat seseorang dalam mengambil keputusan. Dalam penelitian ini, faktor religiusitas menjadi variabelyang mampu mempengaruhi keputusan millennial di Jabodetabek dalam mengeluarkan dana ZIS mereka. Hal ini karena religiusitas atau komitmen beragama berperan penting bagi kehidupan dalam membentuk keyakinan, pengetahuan, dan sikap (Salleh 2012).

\section{KAJIAN PUSTAKA PEGEMBANGAN HIPOTESIS \\ Keputusan Konsumen}

Menurut Kotler dan Keller, keputusan merupakan sebuah proses pendekatan dalam upaya menyelesaikan masalah yang terdiri dari tahapantahapan yakni pencarian informasi, penilaian beberapa alternatif, merumuskan keputusan membeli dan perilaku setelah membeli yang dilalui konsumen. Sedangkan definisi dari keputusan konsumsi menurut Boyd dan Walker adalah sebuah pendekatan penyelesaian masalah pada kegiatan manusia mengonsumsi suatu produk guna memenuhi keinginan dan kebutuhan (Boyd and Walker 2013).

Keputusan konsumen ini menunjukkan perilaku seseorang terhadap mengonsumsi suatu barang atau jasa. Perilaku konsumen tersebut menurut Schiffman dan Kanuk, merupakan perilaku yang memperlihatkan konsumen dalam mencari, membeli, menggunakan, mengevaluasi serta menghabiskan produk dan jasa yang diharapkan akan memuaskan kebutuhan atau keinginannya.

Konsumen yang dimaksudkan pada penelitian ini adalah muzakki yang berarti setiap orang yang wajib membayar zakat setelah mencapai nisab dan haul, serta munfiq atau orang yang membayar infaq dan shadaqah secara sukarela. Dimana muzakki dan munfiq ini menjadi konsumen pengguna aplikasi pembayaran ZIS digital. Hal-hal yang mempengaruhinya dapat muncul dari dalam diri konsumen itu sendiri seperti halnya motivasi, kepribadian, persepsi, maupun kepercayaan, serta dapat pula dipengaruhi oleh faktor luar misalnya budaya, lingkungan sekitar, kelas sosial, opini masyarakat, bahkan pengaruh media sosial online (Kotler and Armstrong 2016). Berasal dari rangsangan internal dan eksternal tersebut, Kotler membuat suatu model perilaku konsumen. Mulai dari faktor yang mempengaruhi hingga perilaku konsumen dalam mengonsumsi, sebagai berikut:

\section{Gambar 2. Model Perilaku Konsumen}

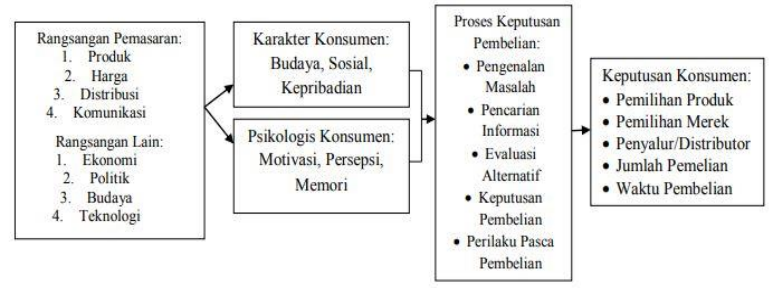

Sumber: Kotler \& Keller, 2009

\section{Intensi Perilaku}

Intensi merupakan perubahan yang paling dekat dengan perilaku yang dilakukan oleh individu, dan merupakan perubahan yang menjembatani anatra sikap dan perilaku nyata. Jadi intensi adalah perilaku individu dalam melakukan suatu hal secara terus-menerus. Adapun menurut definisinya, intensi perilaku didefinisikan sebagai ketertarikan seseorang menggunakan atau membeli sesuatu. Intensi ini diyakini memiliki pengaruh 
yang positif signifikan terhadap perilaku individu dalam menggunakan teknologi. Dalam kaitannya dengan pembayaran zakat, infaq dan sedekah melalui platform ZIS digital adalah untuk melihat sikap individu dalam keputusannya dalam membayar ZIS melalui platform digital (Venkatesh, et al. 2003).

Teori dari intensi perilaku dikembangkan oleh Ajzen dan Fishbein, yang disebut dengan Theory of Planned Behavior (TPB). Teori ini merupakan pengembangan teori dari Theory of Reasoned Reason (TRA) guna mengetahui faktor yang menyebabkan intensi perilaku individu seperti sikap, norma subjektif dan persepsi kontrol perilaku (Huda, Hulmansyah and Rini, 2017).

Menurut Fishbein dan Ajzen, sikap didefinisikan sebagai faktor yang alami dari dalam diri seseorang yang dipelajari guna memberi respon dengan cara yang konsisten yakni suka atau tidak suka pada penilaian terhadap suatu objek yang diberikan (Huda, Rini, et al. 2012). Dalam Islam, sikap disebut dengan akhlak yakni ilmu yang menentukan batas antara baik dan buruk, terpuji maupun tercela atas suatu objek (Herlyana 2012). Terdapat tiga sikap atau akhlak menurut Kamal dan Ghani (2014) dan Huda et al. (2017) yakni akhlak terhadap Allah, akhlak terhadap diri sendiri dan akhlah terhadap sesama manusia.

Pada faktor norma subjektif atau niat, merupakan persepsi yang sifatnya individual terhadap tekanan sosial untuk melakukan atau tidak melakukan suatu perilaku. Norma subjektif atau niat itu sendiri memiliki tiga bagian, yakni niat ibadah, niat ta' at dan niat qurban (Abidin 2012). Sedangkan kendali perilaku yaitu perasaan individu mengenai mudah atau sulitnya mewujudkan suatu perilaku tertentu (Mahyani 2013). Kendali perilaku ini ditentukan oleh keyakinan individu mengenai kekuatan faktor eksternal dan internal dalam memfasilitasi perilaku. Seperti misalnya pengaruh keluarga dalam memilih lembaga zakat.

\section{Religiusitas}

Definisi religiusitas menurut Suhardiyanto (2001) yaitu hubungan yang secara pribadi terjalin antara ilahi Yang Maha Kuasa dengan manusia yang berkonsekuensi untuk melaksanakan kewajiban-Nya dan menjauhi apa yang dilarang oleh-Nya. Oleh sebab itu, religiusitas tidak hanya terjadi ketika seeorang melakukan perilaku ritual (beribadah) saja tetapi juga ketika melakukan aktivitas sehari-hari baik itu yang terlihat oleh mata maupun sesuatu yang terjadi dalam hati dan pikiran seseorang (Wahyudin, et al. 2013).

Konsep religiusitas menurut Stark \& Glock (1994) mengungkapkan bahwa konsep tersebut memperhatikan segala dimensi yang tidak hanya dari segi ibadah ritual tetapi juga aktivitas lain. Lima dimensi religiusitas diantaranya adalah dimensi keyakinan, dimensi praktek agama (ritual), dimensi pengalaman, dimensi pengetahuan agama,dimensi pengamalan atau konsekuensi.

\section{Konsep Zakat, Infaq dan Sedekah Online}

Zakat, Infaq dan Sedekah (ZIS) merupakan salah satu bentuk ibadah yang sangat dianjurkan dalam agama Islam. Selain itu, ZIS juga berperan untuk menyelesaikan permasalahan ekonomi pembangunan khususnya kemiskinan dan ketidakmerataan distribusi pendapatan. Sehingga membayar ZIS ini merupakan hal yang sangat penting dan perlu untuk dikembangkan agar memudahkan wujud ibadah setiap individu muslim. Salah satu cara baru untuk membayar ZIS di era industri 4.0 ini adalah melalui platform digital atau online atau dapat disebut juga dengan ZIS online.

Zakat, infaq dan sedekah (ZIS) online ini merupakan suatu proses pembayaran ZIS yang dilakukan secara digital atau online dimana muzaki yang hendak membayar ZIS tidak perlu ke tempat pembayaran zakat ataupun bertemu langsung dengan para amil. Dalam syariah, praktik pembayaran ZIS ini diperbolehkan karena mengikuti perkembangan zaman dan kemajuan teknologi yang semakin memberikan kemudahan. Selain itu, kondisi figh nya pun mengikuti, yakni adanya ijab dan qobul tidak secara langsung dikarenakan amil dan muzaki tidak bertemu. Oleh karena itu ucapan doa yang diucapkan apabila muzaki menyerahkan zakat kepada amil dapat dikirim melalui sms (Aziz 2017).

Hal tersebut sesuai dengan pernyataan Yusuf Al Qardhawi dalam bukunya figh zakat yaitu seseorang boleh tidak menyatakan secara eksplisit bahwa dana yang ia berikan adalah zakat. Artinya seorang muzaki boleh tidak menyatakan uang yang diberikannya merupakan uang zakat pada amil zakat dan zakatnya tersebut dianggap tetap sah. Maka dari itu zakat secara online kepada amil zakat tetap diperbolehkan (Berzakat 2017).

Berdasarkan Outlook Zakat Indonesia (2019) yang diterbitkan oleh BAZNAS, terdapat tiga jenis platform digital yang dapat digunakan untuk membayar ZIS, yakni:

a. Internal Platform, yakni platform yang dikembangkan oleh organisasi pengelola zakat itu sendiri dalam bentuk website atau aplikasi. Contohnya Muzaki Corner yang dimiliki BAZNAS, dtpeduli.org, Zakat Apps yang dimiliki Sinergi Foundation;

b. Eksternal Platform, adalah platform yang disediakan mitra organisasi pengelola zakat 
untuk menghimpun dana ZIS. Seperti melalui e-commerce (tokopedia, bukalapak, lazada, elevenia, blibli), online crowdfunding (KitaBisa.com), QR Code (GoJek);

c. Media Platform, merupakan metode pengumpulan dana ZIS melalui media sosial seperti misalnya OY! Indonesia.

\section{METODE PENELITIAN}

Metode yang digunakan pada penelitian ini adalah metode survey dengan pendekatan eksplanatoris. Karakteristik dari metode ini adalah kuanitatif yang bertujuan untuk meneliti perilaku suatu individu atau kelompok dengan mengambil sampel dari satu populasi dengan menggunakan kuesioner sebagai alat pengumpulan data.

Populasi dalam penelitian ini adalah muzakki dan munfiq yang termasuk generasi millennial (1981-2000) dengan usia 19 tahun hingga 38 tahun. Sedangkan dalam menentukan sampel muzakki dan munfiq, peneliti menggunakan teknik pengambilan sampel non-probability sampling dengan jenis purposive sampling dimana karakter dari jenis sampel tersebut didasarkan pada kebutuhan penelitian dengan kriteria yang ditentukan oleh peneliti.

Metode dan analisis yang digunakan adalah analisis PLS-SEM melalui software SmartPLS 3.0. Dimana metode tersebut merupakan metode yang memiliki karakteristik bahwa data tidak harus berdistribusi normal, dapat menganalisis semua jenis data, serta jumlah sampel yang digunakan kecil. Dalam SEM, variabel endogen adalah variabel yang dipengaruhi oleh eksogen dimana pada penelitian ini terdapat keputusan membayar zakat secara digital sebagai variabel ndoMaka dari metode tersebut, dapat menghasilkan model penelitian seperti berikut:

\section{Gambar 3. Output Model Penelitian}

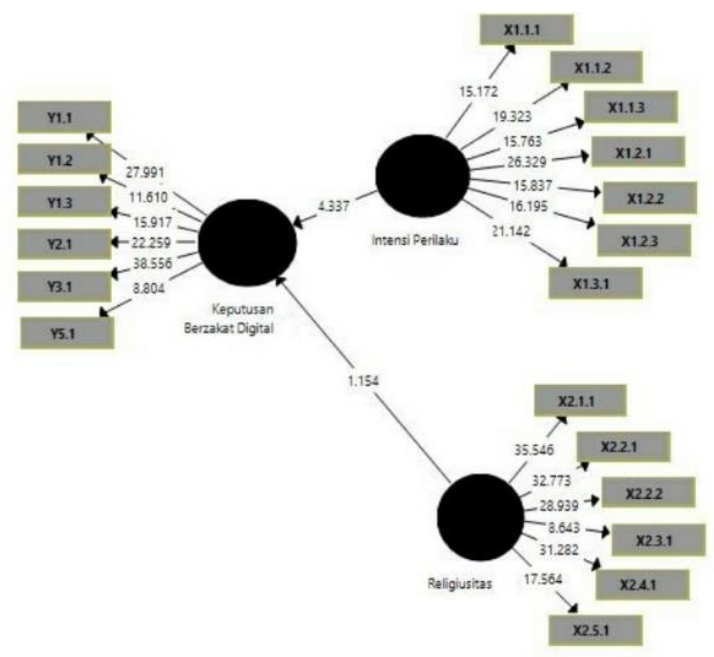

Sebagaimana yang terlihat pada gambar diatas, bahwa intensi perilaku dan religiusitas memiliki pengaruh terhadap keputusan berzakat digital, maka hipotesis untuk penelitian ini adalah: $\mathrm{H} 1$ : Intensi perilaku memiliki pengaruh signifikan terhadap keputusan berzakat digital

$\mathrm{H} 2$ : Religiusitas memiliki pengaruh signifikan terhadap keputusan berzakat digital.

\section{HASIL DAN PEMBAHASAN Hasil Uji Kelayakan Model}

Goodness of Fit (GoF) atau uji kebaikan model dilakukan untuk mengetahui seberapa baik model penelitian yang digunakan dengan data penelitian yang diperoleh. Analisis data dengan menggunakan PLS-SEM mengharuskan perhitungan secara manual untuk mengetahui nilai GoF.

Adapun nilai rata-rata Average Varian Extracted (AVE) dalam penelitian ini berdasarkan data yang diperoleh, yakni sebesar 0.646 dan nilai $\mathrm{R}^{2}$ adalah sebesar 0.295. Berikut hasil perhitungan Uji kelayakan model:

$\mathrm{GoF}=\sqrt{A V E} x R^{2}$

$\mathrm{GoF}=\sqrt{0.646} \times 0.295=\sqrt{0.19057}=0.437$

Nilai GoF yang didapat adalah sebesar 0.437 mengindikasikan bahwa model yang dibangun memiliki Goodness of Fit yang sangat baik karena melebihi nilai batas yang ditentukan yaitu 0.38 .

\section{Pengaruh Intensi Perilaku Terhadap Keputusan Membayar ZIS Digital}

Hasil penemuan di lapangan, muzakki dan munfiq millennials di Jabodetabek memiliki intensi untuk berzakat, infaq dan sedekah melalui platform digital yang cukup tinggi. Hal ini dibuktikan dengan nilai $\mathrm{T}$ statistics intensi perilaku sebesar 4.337, dimana nilai tersebut lebih dari 1.975 yang berarti intensi perilaku berpengaruh signifikan bagi keputusan untuk menunaikan zakat secara online.

Hasil ini juga sesuai dengan teori yang dikemukakan oleh Ajzen (2005), dimana perilaku konsumen dalam mengonsumsi barang atau jasa akan dipengaruhi oleh intensi perilaku yang diukur oleh sikap, norma subjektif dan kendali perilaku. Begitupula dengan hasil penelitian yang dilakukan oleh Lusiana dan Zilal (2017), Wahyudin, Siti, dan Larisa (2018), serta Utari, Itsla dan Aisa (2019) menyatakan bahwa itensi perilaku memiliki pengaruh signifikan terhadap keputusan membayar Zakat Infaq dan Sedekah. Namun tiga penelitian tersebut menggunakan media pembayaran yang berbeda dengan penelitian ini.

Walaupun demikian, tetap dapat disimpulkan bahwa seorang individu dalam memutuskan untuk menunaikan zakat, berinfaq maupun bersedekah sangat dipengaruhi oleh 
sikapnya sendiri, norma subjektif seperti kepercayaan dari orang lain serta kendali perilaku pribadi. Salah satunya seperti muncul keinginan untuk menolong sesama, untuk menambah amal shaleh, atau mengikuti anjuran syariat agama. Selain itu, mereka juga dipengaruhi oleh faktor citra atau reputasi lembaga yang menyediakan layanan platform ZIS digital. Kredibilitas dari penyedia layanan tersebut sangat diperhitungkan karena menentukan arah dana yang akan mereka berikan ataupun program donasi yang sedang dilakukan oleh lembaga zakat, infaq dan sedekah tersebut. Seperti misalnya membuka donasi ke Palestina, program donasi Al Quran, atau program zakat fitrah di bulan Ramadhan. Kemudian, terdapat pula dorongan dari lingkungan sosial yang memberikan nilai bagi seorang individu jika melakukan donasi atau zakat tersebut. Oleh sebab itu tingkat intensi individu dalam mengambil keputusan untuk menunaikan zakat, berinfaq dan bersedekah dikategorikan cukup tinggi.

\section{Pengaruh Religiusitas Terhadap Keputusan Membayar ZIS Digital}

Berbeda dengan intensi perilaku, religiusitas millennial di Jabodetabek ternyata tidak berpengaruh secara signifikan terhadap keputusan dalam mengeluarkan ZIS. Hal ini terbukti dengan nilai $\mathrm{T}$ statistics religiusitas menunjukkan hasil sebesar 1.154 , dimana nilai tersebut kurang dari 1.975. Didukung dengan hasil P statistics sebesar 0.249 , nilai tersebut kurang dari 0.05 sebagai batas nilai. Oleh sebab itu, dapat dikatakan bahwa religiusitas berpengaruh secara tidak signifikan bagi keputusan membayar ZIS digital.

Berdasarkan hasil tersebut maka religiusitas yang diukur melalui ritual, keyakinan, penerapan, pengetahuan dan bentuk pengalaman individu dalam beribadah ternyata tidak mempengaruhi muzakki dan munfiq Jabodetabek dalam memutuskan untuk berzakat, infaq dan sedekah melalui platform digital. Padahal dalam beberapa penelitian terdahulu seperti Shah Alam (2011), Mokhlis (2009), dan Riska, Dewi dan Westi (2015) menyatakan bahwa religiusitas sangat mempengaruhi keputusan seseorang dalam melakukan sesuatu khususnya dalam melakukan kegiatan konsumsi. Dalam penelitian tersebut pula dinyatakan bahwa para muzakki yang mengeluarkan uang untuk berzakat, infaq dan sedekah memiliki keyakinan bahwa hartanya tersebut akan dilipatgandakan selain karena zakat merupakan rukun Islam yang ketiga. Maka dapat dikatakan bahwa semakin tinggi religiusitas responden, maka kecenderungan responden untuk membayar ZIS semakin tinggi, terkhusus ZIS digital.

Namun hasil penelitian ini sama dengan yang dilakukan oleh Aditya dan Ahmad (2019), dan Nasrullah (2015) yang menyatakan bahwa religiusitas berpengaruh tidak signifikan terhadap keputusan seseorang dalam melakukan sesuatu khususnya dalam menunaikan zakat. Dalam penelitian yang dilakukan Aditya dan Ahmad (2019) menyebutkan, salah satu faktor yang membuat religiusitas tidak mempengaruhi keputusan menunaikan zakat adalah kurangnya pemahaman dan pengetahuan individu, khususnya pegawai Kementerian Agama Kabupaten Semarang. Sehingga apabila dikaitkan dengan penelitian ini terdapat kemungkinan bahwa kelompok millennial memiliki pemahaman dan pengetahuan yang kurang akan makna dan hakikat dari mengeluarkan ZIS terkhusus bagi kaum muslim. Terlebih pada kenyataannya, faktor kaum millennial membayar ZIS didominasi oleh nilainilai sosialnya saja, bukan dari nilai spiritualnya.

\section{KESIMPULAN}

Berdasarkan hasil pemaparan yang telah dilakukan sebelumnya, dapat ditarik tiga kesimpulan yakni intensi perilaku millennial di Jabodetabek memiliki pengaruh yang signifikan atas keputusan untuk membayar ZIS melalui platform online. Indikator tertinggi yang membuktikannya adalah dengan kemudahan yang diberikan oleh platform online sehingga kaum millennial berminat untuk mengeluarkan ZIS. Indikator lainnya yang mempengaruhi keputusan membayar ZIS melalui platform online adalah lingkungan sosial serta faktor lain seperti reputasi lembaga amil yang mampu memberikan rangsangan pada millennial Jabodetabek untuk berzakat, infaq, dan sedekah.

Reputasi lembaga sangat mempengaruhi keputusan millennial dalam membayar ZIS melalui platform online, karena reputasi suatu lembaga berkaitan dengan tepercaya atau tidaknya distribusi dana ZIS yang sudah disalurkan oleh para munfiq dan muzakki. Sebelum era industri 4.0 muncul, masyarakat cenderung lebih percaya untuk menyalurkan dana ZIS secara langsung, namun di era saat ini semuanya sudah sangat berkembang dan mudah.

Selanjutnya, hasil penelitian ini pun menunjukkan bahwa religiusitas memberikan pengaruh yang tidak signifikan terhadap keputusan millennial di Jabodetabek dalam mengeluarkan zakat, infaq, dan sedekah secara online. Landasan keagamaan kaum millennial tidak serta merta menjadi fondasi kuat yang mampu mendorong mereka untuk mengeluarkan dana ZIS. Melihat 
fakta tersebut, dapat menjadi saran bagi para stakeholders untuk lebih mengoptimalkan penghimpunan ZIS dengan beberapa strategi, yaitu seperti memberikan pemahaman tentang konsep, hikmah, dan manfaat zakat, infaq, dan sedekah. Pemahaman pun meliputi sumber-sumber harta objek ZIS, cara penghitungannya, ataupun dengan menguatkan keyakinan bahwa semua perbuatan akan mendapat balasan baik di dunia secara langsung maupun kelak di akhirat. Strategi lainnya yang dapat dilakukan adalah dengan membuat sebuah ajakan atau imbauan untuk secara rutin hadir ke majelis ilmu, menyadarkan kembali untuk membantu fakir miskin, dan adanya hak orang lain dalam setiap harta yang dimiliki. Strategi-strategi tersebut dapat dilakukan dengan mengoptimalkan media sosial sehingga dapat menjangkau masyarakat lebih luas lagi, khususnya pada kelompok millennial yang sangat aktif menggunakan media sosial.

\section{REFERENSI}

Abidin, Zaenal. 2012. "Rahasia Hukum Islam Dalam Ruang Peribadatan." Jurnal Adabiyah Vol 12 No 2.

Alam, Syed Shah, Rohani Mohd, and Badrul Hisham. 2011. "Is Religiosity an Important Determinant on Muslim Consumer Behaviour in Malaysia?" Journal of Islamic Marketing Vol. 2 83-96.

Avisena, M Ilham Ramadhan. 2020. Ekonomi. Januari 30. https://mediaindonesia.com/read/detail/28 6776-kelas-menengah-berkontribusibesar-pada-pertumbuhan-ekonomi.

Aziz, A Fauzi. 2017. "Analisis Istinbat Hukum Akad Perkawinan Melalui Media Elektronik Dalam Perspektif Hukum Islam." Tafaqquh: Jurnal Penelitian dan Kajian Keislaman 102-117.

Badan Pusat Statistik. 2019. Keadaan Angkatan Kerja Provinsi DKI Jakarta. Statistik, Jakarta: Badan Pusat Statistik. Accessed 10 06, 2019. https://www.bps.go.id.

BAZNAS. 2019. Indikator Pemetaan Potensi Zakat. Jakarta: Pusat Kajian Strategis Badan Amil Zakat Nasional.

BAZNAS. 2018. Outlook Zakat Indonesia. Statistics, Jakarta: BAZNAS.

Berzakat. 2017. Filantropi. June 23. https://suaramuslim.net/hukum-zakat-viaonline/.

Boyd, Harper W., and Orville C. Walker. 2013. Marketing Management: a strategic decision making approach. New York: New York McGraw-Hill.
Cahyani, Utari Evy, Itsla Yunisva Aviva, and Aisa Manilet. 2019. "Faktor Faktor yang Mempengaruhi Intensi Muzakki dalam Membayar Zakat di Lembaga." Tazkir: Jurnal Penelitian Ilmu Sosial dan Keislama 39-59.

Hardinawati, Lusiana Ulfa, and Muhammad Zilal Hamzah. 2017. "Analisis Faktor yang Mempengaruhi Intensi Donatur Membayar Zakat, Infak, dan Sedekah Melalui Bank." Jurnal Middle East and Islamic Studies Vol. 4 175-193.

Haryano, Agus Tri. 2019. Telekomunikasi. Mei 16. https://inet.detik.com/telecommunication/ d-4551389/pengguna-internet-indonesiadidominasi-milenial.

Herlyana, Elly. 2012. "Fenomena Coffee Shop Sebagai Gejala Gaya Hidup Baru Kaum Muda." Thaqafiyyat Vol. 13 187-204.

Huda, Nurul, Hulmansyah, and Nova Rini. 2017. "Faktor Yang Mempengaruhi Perilaku Konsumsi Produk Halal Pada Kalangan Mahasiswa Muslim." Ekuitas: Jurnal Ekonomi dan Keuangan 247-270.

Huda, Nurul, Nova Rini, Yosi Mardoni, and Purnama Putra. 2012. "The Analysis of Attitudes, Subjective Norms, and Behavioral Control on Muzakki's Intention to Pay Zakah." International Journal of Business and Social Science 271 - 280.

Kamal, Siti Soraya Lin Abdullah, and Faizah Abd. Ghani. 2014. "Emotional Intelligence and Akhlak Among Muslim Adolescents in One of the Islamic Schools in Johor, South Malaysia." 4th World Conference on Psychology, Counseling and Guidance. Istanbul, Turkey: Elsevier Ltd. 687-692.

KNKS. 2019. "Tumbuh Bersama, Meningkatkan Kesejahteraan Masyarakat Melalui Pemerataan Zakat." Insight Buletin Ekonomi Syariah.

Kotler, Philip, and Gary Armstrong. 2016. Principles of Marketing. New Jersey: Pearson Education.

Mahyani, Dr. 2013. "Theory of Reasoned Action dan Theory of Planned Behavior (Sebuah Kajian Historis Tentang Perilaku)." Jurnal El Riyasah Vol 4, No 1 13-24.

Mokhlis, S. 2009. "Relevancy and Measurement of Religiosity in Consumer Behaviour Research." International Business Research Vol. 2 75-84.

Salleh, Muhammad Syukri. 2012. "Religiosity in Development: A Theoretical Construct of an Islamic-Based Development." International Journal of Humanities and Social Science. Vol.2 No.14. 
Santoso, Ivan Rahmat. 2019. "Strategy for Optimizing Zakat Digitalization in Alleviation Poverty in the Era of Industrial Revolution 4.0." IKONOMIKA: Jurnal Ekonomi dan Bisnis Islam Volume 4, No. 1 35.

Stark, Rodney, and Charles Y. Glock. 1968. American Piety: The Nature of Religious. Barkeley, USA: University of California Press.

Venkatesh, Viswanath, Michael G Morris, Gordon B Davis, and Fred D Davis. 2003. "User Acceptance of Information Technology: Toward A Unified View." Mis Quarterly $425-479$.
Wahyudin, Larisa Pradisti, Sumarsono, Siti Zulaika, and Wulandari. 2013. "Dimensi Religiusitas dan Pengaruhnya Terhadap Organizational Citizenship Behaviour (Studi Pada Universitas Jenderal Soedirman Purwokerto)." Jurnal Ekonomi Bisnis dan Akuntansi 1-13.

Wardhani, Riska Satia, Dewi Rahmi, and Westi Riani. 2015. "Faktor-Faktor yang Mempengaruhi Muzakki dalam Menyalurkan Zakat Melalui Lembaga Amil Zakat." Dinamika Ekonomi: Jurnal Ekonomi dan Pembangunan Vol.11 1-15. 